Abstracta Iranicacta Iranica

Revue bibliographique pour le domaine irano-aryen

Volume 32-33 | 2013

Comptes rendus des publications de 2009-2010

\title{
Marc Gaborieau. Le mahdi incompris. Sayyid Ahmad Barelwî (1786-1831) et le millénarisme en Inde
}

\section{Fabrizio Speziale}

\section{(2) OpenEdition \\ 12 Journals}

Édition électronique

URL : http://journals.openedition.org/abstractairanica/40629

DOI : 10.4000/abstractairanica.40629

ISSN : 1961-960X

\section{Éditeur :}

CNRS (UMR 7528 Mondes iraniens et indiens), Éditions de l'IFRI

\section{Édition imprimée}

Date de publication : 1 décembre 2013

ISSN : 0240-8910

\section{Référence électronique}

Fabrizio Speziale, «Marc Gaborieau. Le mahdi incompris. Sayyid Ahmad Barelwî (1786-1831) et le millénarisme en Inde », Abstracta Iranica [En ligne], Volume 32-33 | 2013, document 274, mis en ligne le 01 juillet 2016, consulté le 29 septembre 2020. URL : http://journals.openedition.org/abstractairanica/ 40629 ; DOI : https://doi.org/10.4000/abstractairanica.40629

Ce document a été généré automatiquement le 29 septembre 2020.

Tous droits réservés 


\title{
Marc Gaborieau. Le mahdi incompris. Sayyid Ahmad Barelwî (1786-1831) et le millénarisme en Inde
}

\author{
Fabrizio Speziale
}

\section{RÉFÉRENCE}

Marc Gaborieau. Le mahdi incompris. Sayyid Ahmad Barelwî (1786-1831) et le millénarisme en Inde. Paris, CNRS Editions, 2010, 339 p.

1 Cette monographie sur Sayyid Aḥmad Barelwī (m. 1831), figure influente de l'islam indo-pakistanais modern, offre une importante contribution à l'étude du réformisme religieux musulman en Asie du sud. L'A. revient de façon critique sur les différents aspects et étapes de la carrière de ce personnage complexe, aux multiples facettes. Chef et réformateur religieux, influencé par le soufisme dont cependant il condamna durement les excès, considéré comme le Mahdi par ses disciples, il fut également un chef militaire, il prêcha la jihad et aujourd'hui des groupes tels les talibans d'Afghanistan lui regardent comme leur précurseur. L'ouvrage examine les préceptes de Sayyid Ahmad, les caractéristiques de son mouvement, ainsi que les rapports avec les autres courants du réformisme indo-musulman de l'époque coloniale, tandis que la dernière partie est consacrée à la construction de la figure du mahdi. L'A. analyse également le rôle d'une autre figure clé du mouvement, Šāh Ismā'îl Šahīd (1779-1831), disciple de Sayyid Ahmad et auteur des principaux écrits qui exposent les doctrines du mouvement. 


\section{AUTEURS}

\section{FABRIZIO SPEZIALE}

Université Sorbonne Nouvelle-Paris 3/Mondes iranien et indien, Paris 